\title{
ECONOMICS
}

\section{A. C. PIGOU'S REJECTION OF PARETO'S LAW}

\author{
by
}

Michael McLure

Business School

The University of Western Australia

DISCUSSION PAPER 11.14 


\title{
A. C. Pigou's Rejection of Pareto's Law
}

\author{
by \\ Michael McLure ${ }^{1}$ \\ Economics Program \\ Business School \\ The University of Western Australia
}

Draft Version: 25 August 2011

\section{DISCUSSION PAPER 11.14}

\begin{abstract}
In Pigou's Wealth and Welfare, as well as in each of the four editions of his The Economics of Welfare, one chapter is dedicated entirely to the critical assessment, and ultimate rejection, of 'Pareto's law' of income distribution. This note highlights Pigou's uncorrected misreading of a critical aspect of Pareto's analysis of income distribution; illustrates what his criticisms of Pareto's law reveal about Pigou's objectives for welfare economics; and indicates how Pareto's analysis of income distribution could have been criticised in a manner that is consistent with Pigou's objectives for welfare economics.
\end{abstract}

Key Words: Income distribution; Pareto's Law, Pigou, Economic Welfare

\footnotetext{
${ }^{1}$ An earlier version of this paper was presented at the annual HETSA Conference, RMIT University, Melbourne 6-8 July 2011. I would like to thank Rebecca Doran-Wu for preparing the figures for insertion in this paper.
} 
It is through induction that we know the form of the curve of income; and it is deduction that permits us to derive two very important theorems. The first of these theorems teaches us that the distribution of income is not due to chance. The second tells us that to increase the level of the minimum income or to reduce the inequality of income it is necessary that wealth increase more rapidly than population.

Vilfredo Pareto, 1897 Cours d'Économie Politique, vol.2 


\section{Introduction}

The secondary literature on 'Pareto's law' is extensive ${ }^{2}$ and historical studies, such as those by Joseph Persky (1992) and Terenzio Maccabelli (2009), have provided significant retrospective assessments of the debate pertaining to this law and its relationship to the question of income inequality. A. C. Pigou was one of the more influential contributors to the secondary literature on this topic with a full chapter in Wealth and Welfare (Pigou 1912), as well as a full chapter in each of the four editions of The Economics of Welfare (Pigou 1932), dedicated to rejecting the second theorem cited in the above quotation, which Pigou considers as 'Pareto's law'. In the historical literature, Pigou's assessment is typically considered from the perspective of the critical insights that it brings to our understanding of the limitations of Pareto's law. But the rather vigorous mode of his largely flawed criticism of Pareto's law suggests that his approach to this law is also relevant to the development of an understanding of Pigou's general approach to welfare theory.

The purpose of this note is to consider Pigou's motivation for writing his critical assessment of 'Pareto's law'. There are four objectives associated with that purpose. First, to overview the form of the Pareto distribution of income and graphically illustrate the intuition that underlies Pareto's deduction of his second theorem (section 2). Second, to critically evaluate Pigou's assessment of 'Pareto's law' and, in the process, highlight the flaws in his analysis (section 3). Third, to consider Pigou's motivation for rejecting Pareto's law in terms of Pigou's overall objectives for welfare economics and to suggest an alternate basis for criticising that law that is consistent with those objectives (section 4). Finally, to reflect on whether Pigou's rejection of Pareto's law of income distribution was partly motivated by a desire to apply the marginal theory of distribution, which Pareto had criticised, when developing the Pigouvian relationship between wealth and welfare (section 5). The paper ends with a brief conclusion (section 6).

\footnotetext{
${ }^{2}$ A comprehensive sample of the English language secondary literature on Pareto's law is included in volume 4 of Vilfredo Pareto: Critical Assessments (Wood and McLure 1999).
} 


\section{Pareto's Law}

Pareto $(1896,1897)$ investigated whether the curve of distribution of income was associated with any particular form. For the levels of income above some arbitrarily determined minimum, he posited that income distribution may be represented by three possible forms of various degrees of generality. Much of his discussion concerned the following two forms:

(1) $\quad N_{x}=\frac{A}{(x+a)^{\alpha}}$

$\left(1^{*}\right) \quad \log N=\log A-\alpha \log (x+a)$

(2) $\quad N_{x}=\frac{A}{x^{\alpha}}$

$\left(2^{*}\right) \quad \log N=\log A-\alpha \log x$
$x$ : a level of income
$N_{x}$ : number of people with an income of at least $x$
$A$ : parameter
$a$ : parameter
$\alpha$ : parameter 
Figure 1: Equation 2

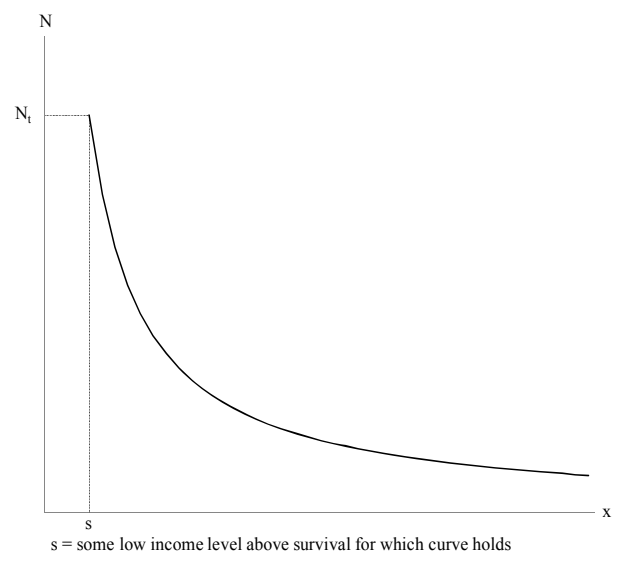

Figure 2: Equation 2*

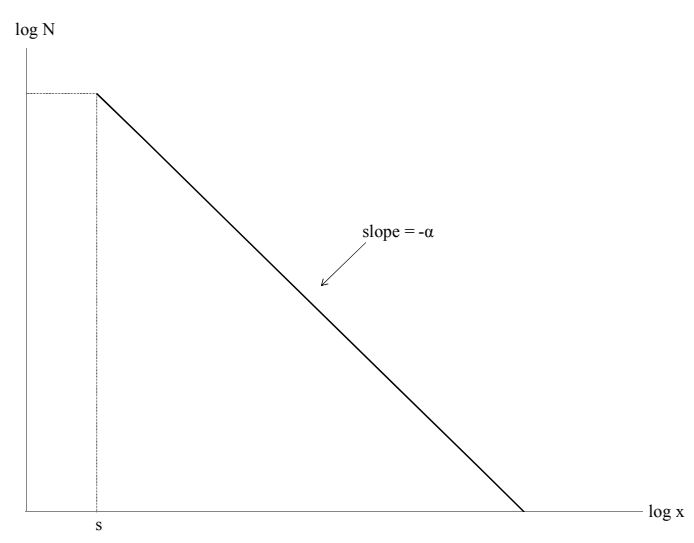

Based on his empirical tests of income tax data from many $19^{\text {th }}$ Century cities, regions and countries - such as England, Ireland, Italy, Prussia, Saxony, Peru, The Grand Dutchy of Oldenburg, Vaud, Paris, Florence (as well as data from $15^{\text {th }}$ and $16^{\text {th }}$ Century for some Swiss cities Basel and Augusta) - Pareto found that the form of the curve of distribution may be represented by the above equations as reasonable general approximations. As the parameter $a$ was usually found to be very small, the more general form of income distribution represented by equations 1 or $1^{*}$ was sometimes set aside in favour of the simplified equations 2 or $2^{*} .3$ From his empirical results Pareto concludes that income is not distributed normally by pure chance, which is his first theorem. Instead:

(i) inequality is a general characteristic of the distribution of income;

(ii) the non-normal distributions of equations 1 and 2 provide a reasonable approximation to the income distribution curve; and

\footnotetext{
3 The most general form the of income distribution curve that Pareto developed was actually $N_{x}=\frac{A}{(x+a)^{\alpha}} e^{-\beta x}$, but as the exponential term $e^{-\beta x}$ tended to approach 1 that form of the curve was generally set aside.
} 
(iii) the estimate value of $\alpha$, the slope of the double $\log$ form of the Pareto distribution, lies between 1.29 and $1.89^{4}$ although the average result was in the general vicinity of 1.5 .

Pareto's second theorem was derived from extensive deductive analysis, but such deductions were still undertaken in reference to his empirically estimated curve of income distribution. He posited that an index of equality/inequality in income distribution $\left(u_{x}\right)$, which increases as inequality diminishes, ${ }^{5}$ may be represented by a quotient of the number of people $\left(N_{x}\right)$ accruing income at least some arbitrary level $x$, and, the number of people $\left(N_{h}\right)$ accruing at least the minimum income $h$. Given the form of the income distribution curve represented, Pareto measured income equality as quotients of equation 1: for the numerator, the reference value of income is $x$; for the denominator, the reference value for income is $h$. To simplify the analysis in this note, Pareto's index of equality/inequality is represented by ratios of equation 2 (the reduced form of equation 1 in which parameter $a$ is removed) and shown in equation 3 below.

(3) $u_{x}=\left(\frac{N_{x}}{N_{h}}\right)=\frac{\frac{A}{x^{\alpha}}}{\frac{A}{h^{\alpha}}}=\left(\frac{h}{x}\right)^{\alpha}$

Pareto (1897 [1971], pp. 998-999) derives his second theorem from his index of equality/inequality, that is, from equation 3 , by considering the implications for income inequality associated with two specific cases. For convenience, in this paper these two cases are referred to as 'case 1' and 'case 2'.

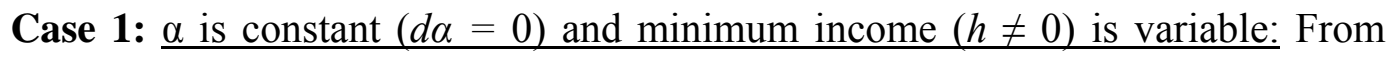
equation 3, an increase in the minimum income $h$ necessarily leads to a reduction in the extent of income inequality. As $d \alpha$ is zero in this case, Pareto concluded that the increase in minimum income can only be realised in conjunction with (i) a general increase in the

${ }^{4}$ Excludes estimates for $15^{\text {th }}$ and $16^{\text {th }}$ Century 'Augusta' and $18^{\text {th }}$ Century Peru, for which the data were considered 'uncertain'.

${ }^{5}$ Pareto never used the phrase 'index of equality/inequality', rather, he preferred to simply emphasise that an increase in the index means a reduction in inequality: "income inequality will diminish with an increase in $u_{x}$ ” (Pareto 1897 [1971], p. 997). 
aggregate value of taxable income when the number of taxpayers is unchanged, or, (ii) when mean taxpayer income increases faster than the increase in the number of taxpayers. The result is graphically illustrated in Figure 3 - in which the initial distribution is shown with a dashed line (with the initial minimum income given by $h$ ) and the new distribution is shown with a solid line (with the new minimum income given by $\left.h^{*}\right)$ - for the situation where the number of taxpayers is unchanged. ${ }^{6}$

Case 2: $\underline{\alpha}$ is variable $(d \alpha \neq 0)$ and minimum income $(h=0)$ is constant. To consider this case, Pareto expressed both sides of equation 3 in logarithmic terms and demonstrated that the change in $\log u_{x}$, which he labels $d u_{x} / u_{x}$, is related to the product of the logarithm of ratio $(h / x)$ and the change in $\alpha$. When $h$ and the taxpayer population are unchanged, the logarithm of the ratio $h / x$ is necessarily negative because the minimum income $h$ must be less that the arbitrarily selected income level $x$. Consequently, an improvement in the equality of income distribution $\left(d u_{x} / u_{x}\right.$ is positive) is only possible when there is a reduction in $\alpha$ ( $d \alpha$ is negative). This case is simply illustrated in Figure 4 below, which illustrates the initial income distribution with a dashed line and the new income distribution with a solid line and reveals that the increase in income equality due to a reduction in $\alpha$ is also associated with an increase in the area under the Pareto distribution, which indicates an increase in taxable incomes. When the number of taxpayers vary over time, the equivalent result is achieved when a reduction in $\alpha$ is associated with an increase in taxpayers' mean taxable income (or real per capita income to grow when considering the entire economy).

\footnotetext{
6 Pareto verifies this result algebraically for the case of equation 1, but when the same procedure is applied to the simpler case of equation $2, d z_{x}$, the change in the mean taxpayer income, is represented by:
}

(4) $d z_{x}=\frac{\alpha}{\alpha-1} d h$ 
Figure 3: Case 1 - based on Equation 2*

$$
\Delta \mathrm{h} \neq 0 \quad \Delta \alpha=0
$$

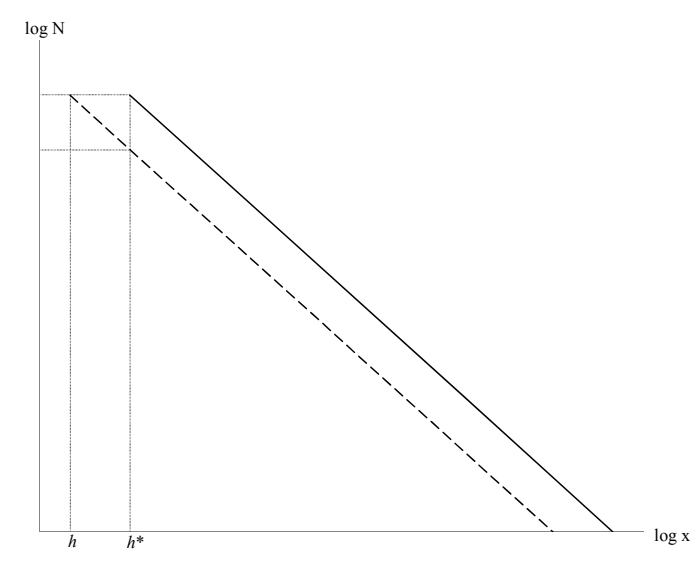

Figure 4: Case 2 - based on Equation 2*

$$
\Delta \mathrm{h}=0 \quad \Delta \alpha \neq 0
$$

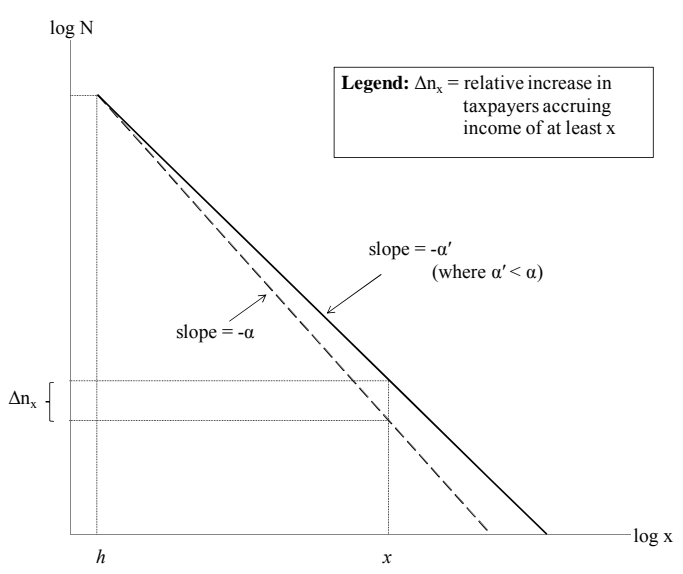

In light of the results of these two cases, Pareto is able to state his second theorem under which real per capita growth is a pre-requisite for an increase in the minimum income level or a reduction in income inequality. In other words, the deductive dimension to Pareto's approach to inequality reflects a 'trickle-down' view of the distribution of benefits from the growth process, conditional upon the minimum income level rising or, at the very least, not falling.

Significantly, Vincent Tarascio (1973, p. 533) has observed that these aspects of Pareto's work "have been completely overlooked by members of the economics profession in spite of the interest in Pareto's Law." That is, economists interest in Pareto's Law has mainly centred on the form of the Pareto distribution (i.e. equations 1 and 2) and the role played by $\alpha$ in that distribution, and not on the second theorem that Pareto deduced from his investigation of equation 3. In some ways, however, Pigou is an exception to that general interpretative approach because the main objective of his assessment of Pareto's law concerns Pareto's second theorem: he sort to reject it! While Pareto argued that "the problem of improving the conditions of the poor classes is above all a problem of the production of wealth" (Pareto 1897,[1971], p. 1097); Pigou (1912, p.72; 1932, p. 648) attempted to demonstrate that Pareto had failed to prove his case. But, as demonstrated in Sections 3 and 4, Pigou's work in this area is only an exception 
to the general interpretation of Pareto's law in terms of his objective; it does not extend to the means that Pigou employed to achieve his objective.

\section{$3 \quad$ Pigou's Rejection of Pareto's Law}

In Wealth and Welfare, Pigou commences his consideration of the topic by accepting that "the approximation to linear character in the income-curve [equation $2 *$ ] is, indeed, fairly well maintained, at least so far as incomes of moderate amount are concerned" (Pigou 1912 , p.73), ${ }^{7}$ but he considered that the result was limited to the countries and cities examined by Pareto and for the periods of time that Pareto investigated. That is, he appears to broadly accept that the Pareto distribution as a reasonable approximation for the cases investigated. However, he did not accept that the statistical evidence cited by Pareto, or the evidence of subsequent studies, supported the suggestion that $\alpha$ was constant across time.

"The inclination of the curve, though it does not differ widely, still does differ distinctly in the different groups of statistics that have been observed." (Pigou 1912, p.73)

In support of this conclusion, he cites Pareto's own statistical estimates for $\alpha$ as well as those of other scholars like "Mr Bowley" and Rodolfo Benini. When considering the complementary relationship that Pareto perceived between real per capita economic growth and the improvement of income equality, Pigou finds in Wealth and Welfare that Pareto's statistical results are "not so entirely harmonious as he suggests" (1912, p.73). In The Economics of Welfare his language is much stronger, referring to 'defects' (1932, p. 649) in Pareto's statistical interpretation and classing the basis of his statistical reasoning as 'defective' (1942, p.649).

This is the most surprising feature of Pigou's analysis. Pareto's second theorem of income distribution - the very law that Pigou sort to reject - was derived deductively from equation 3, which Pigou did not consider (at least on it in the form specified by

\footnotetext{
${ }^{7}$ In the equivalent section of The Economics of Welfare, Pigou writes: "it is true, the logarithmic income curve - at least for incomes of moderate size - is approximately a straight line” (1932, p. 649).
} 
Pareto). Instead, he associated the result with $\alpha$ being constant over time and, in the process, completely ignored Pareto's discussion of the relationship between the inequality of income distribution and variations in $\alpha$. As such, Pigou appears not to have even recognised that the law he rejected was actually derived from analysis in which the slope of the curve of income distribution was reduced. What then did Pareto write in the Cours d'Économie Politique (1896-97 [1971]) that may have lead Pigou to believe that Pareto regarded $\alpha$ as invariant over time? There is no explicit text asserting that proposition, but perhaps the closest statement to that effect is contained in the summary at the end of the book:

"Experience has revealed to us a rather singular fact: the curve of the distribution of income varies little on average, in space or in in time, in the civil populations for which we have given statistics." (Pareto 1897 [1971], p. 1097)

Pigou may have read 'varies little on average' to mean that Pareto saw no scope at all for policy directed activities to alter income distribution. As Pigou no doubt understood that Pareto's law had the potential to be directly and analytically derived from equation $2^{*}$ if $\alpha$ is assumed to be constant (i.e. case 1 in this paper), he may have just assumed that that was the only relationship from which Pareto derived his law. That assumption may have been reinforced in Pigou's mind by Pareto's illustration of the income distribution curve using $\alpha=1.5$ (Pareto 1897 [1971], p. 987), which is a typical value for $\alpha$. But in commenting that ' $\alpha$ varies little on average', Pareto was certainly not suggesting that change in $\alpha$ was impossible. Rather, he was suggesting that scope for such change was constrained. Otherwise, Pareto would not have: highlighted the relationship between inequality and variation in $\alpha$ in his discussion (i.e. case 2 in this paper); or provided a numeric example with particular values assigned to $h, z$ and $a$ that demonstrates how income inequality increases when the value of $\alpha$ increases from 1.5, in period 1, to 1.6, in period 2 (Pareto 1897 [1971], pp. 1001-1002).

In addition to questioning Pareto's statistical evidence, Pigou also argued that social circumstances not evident in the range of countries and cities examined by Pareto, which were mainly $19^{\text {th }}$ Century European cases, may have the potential to alter the form of the curve of income distribution and/or cause $\alpha$ to change. Chief among these were changes to inheritance laws and variations in the proportions of national dividend earned 
as wages and investment. In general, Pigou argued that society is made up of a number of 'groups', each of which are largely homogenous and the distribution of income within each group is subject to normal Gaussian distribution laws and he then speculated that the non-normal distribution of income that Pareto observed for society as a whole was related to the different sizes and prevalence of the various 'groups' within the broader economy. ${ }^{8}$ But Pigou then asserts that Pareto's statistical analysis covered a period in which the prevailing nineteenth century schemes of inheritance were generally maintained. From this, he insisted that a change in inheritance laws could indeed lead to a change in the form of income distribution. The implication of this objection is that changes to inheritance laws will lead $\alpha$ to become more variable because the form of the distribution curve alters in response to a new assignment of property rights. He then criticises Pareto for failing to recognise in his Cours that empirical laws do not necessarily continue to hold when arrangements related to the assignment of property rights change; and chided him for belatedly recognising this point in the Manuale di Economia Politica (1906 [2006]). ${ }^{9}$ In a similar manner, Pigou speculated that the income distribution curve may alter its form in response to variations away from $19^{\text {th }}$ century European norms in the proportions of income that are 'earned' (from capacities for mental and/or manual work) and that which accrue through returns on investment. ${ }^{10}$

As the preceding discussion has mainly been concerned with Pigou's assessment of Pareto's second theorem on welfare distribution, perhaps some comment on Pigou's understanding of the first theorem, and its relationship to the second, is in order before

\footnotetext{
${ }^{8}$ On this issue, Pigou's observations are not original. He essentially restates, and embellishes upon, what Pareto had written in paragraphs 11 to 15, Chapter 9, of the Manuale di Economia Politica (1906 [2006], pp. 273-274).

${ }^{9}$ Pigou's summary of the cautious note in the Manuale is correct, but he does ignore a similar, although less forcefully stated, warning in the Cours.

"Certainly one can never be too prudent when dealing with purely empirical laws. However, the consequences drawn from this law will always hold, at least in the case of peoples for whom we have seen it [statistically] verified" (Pareto 1897 [1971], p. 985 ).

${ }^{10} \mathrm{He}$ illustrates this matter with respect to three points: (i) income from property is more unevenly distributed than 'earned' income; (ii) the greater the importance of unequal distribution of investment income, then the greater the potential for inequality in the distribution of earned income; and (iii) the distribution of training (an investment of capital in people) may alter the distribution of earned income in a manner that is independent of income from other forms of investment. Consequently, Pigou thought that inequality may diminish in response to: an increase in the ratio of 'earned income' to investment income; or an increase in the ratio of investment spending on the training of workers relative to other forms of capital investment.
} 
concluding this section. In the chapter 'Economic Welfare and the National Dividend' from Wealth and Welfare, Pigou rather curiously associated Pareto's final measure of income inequality with the assessment of standard deviation.

"In a rough general way, the measure afforded by the mean square deviation approach will be concordant with such a measure as that which Pareto obtains by dividing the logarithm of the number of incomes in excess of any amount $x$ into the logarithm of $x$. ." (Pigou 1912, p.25)

But Pareto emphasized the non-normal character of the empirically observed income distribution. While Pigou's discussion of different forms of income reveals some appreciation of this, his suggestion that standard deviation analysis can be employed to asses issues of inequality of income distribution does not sit well with the Pareto's proposition that income distribution is not due to chance. As Allyn Young pointed out in his review of Wealth and Welfare:

"The most serious lapse ... which I have noticed is the loosely demonstrated statement that Pareto's measure of inequality in the distribution of income gives rise to the general agreement with those indicated by standard deviation. Applied to actual incomes, these measures are more apt than not to give precisely opposite results.” (Young 1913, p. 686)

Perhaps even more curiously, Pareto's measure of income equality/inequality, defined in equation 3 of this paper, is not, as Pigou indicates, given by "the logarithm of the number of incomes in excess of any amount $x$ into the logarithm of $x$ ". This represents one possible explanation for his misinterpretation of Pareto's work on this topic.

By holding to the points he raised that have been reviewed in the previous paragraphs, Pigou felt justified in concluding in Wealth and Welfare that "no ground would be given for believing that any given form of the income curve is necessary, in the sense that a cause altering one of these common circumstances would leave it unchanged." (Pigou 1912, p.74). When his statistical concerns related to the intertemporal constancy of $\alpha$ were combined with his recognition of the potential for the introduction of new legal-economic arrangements in regard to property right and changes in the form in which income accrues, Pigou finding in The Economics of Welfare is unequivocal. 
"even if the statistical basis of the "law" were much securer than it is, the law would rarely enable us to assert that any contemplated change must leave the form of income distribution unaltered.” (Pigou 1932, p. 655)

\section{Collective Economic Welfare and Pareto's Law}

Pigou's rejection of Pareto's law was not motivated by a desire to establish an alternative general form of the income distribution. Rather, it was motivated by his desire to (i) acknowledge a potential degree of inconsistency in the criteria that he wanted to apply to welfare economics and (ii) outline a mechanism for resolving that inconsistency. In Wealth and Welfare (1912, p. 66) and The Economics of Welfare (1932, p.123) welfare depends on two fundamental criteria: the size of the national dividend; and the manner in which it is distributed among the community. ${ }^{11}$ Pigou considered issues related to each criterion in isolation and then discussed the extent to which there was, in his words, 'harmony' or 'disharmony' between them. His a priori starting point was that 'absolute harmony' between these two criteria is not possible. Pareto's law challenged that view as it suggested that there was no 'disharmony' between these two welfare criteria. But Pigou wanted to examine this question of 'disharmony' in his welfare economics, which explains why he concluded that:

"no general proposition to the effect that improvements in the quality and in the distribution of the dividend [national income] necessarily go together, can be successfully maintained" (Pigou 1932, p. 655)

Having rejected Pareto's law, he used the 'laws of distribution' to consider: the relationship between the national dividend and the equality of 'marginal net products' (and various hindrances to that equality); and the effect of transfers to the poor, assessed using marginalist applications of largely utilitarian principles. In the case of 'disharmony' between his two welfare criteria, Wealth and Welfare countenances the possibility a trade-off between the level of the national dividend and transfers from the

${ }^{11}$ Wealth and Welfare also includes a third dimension as it is suggested that an improvement in economic welfare is associated with a diminution in the variability of the national dividend, especially that part accruing to the poor $(1912$, p. 66). However, this issue was subsequently absorbed within his study of Industrial Fluctuations (1927). 
'relatively rich' to the 'relatively poor' through the introduction of a 'national minimum' income. In the face of a contraction in the national dividend, a welfare gain is still possible as long as the marginal gain from the transfer of each pound to the poor equals (or exceeds) the welfare loss from that contraction (1912, p. 396). That is, Pigou accepted the possibility of purchasing a net welfare gain by obtaining an improved distribution of income (a gain in terms of his $2^{\text {nd }}$ welfare criterion) through a reduction in the national dividend (a loss in terms of his $1^{\text {st }}$ welfare criterion). For such a net welfare gain to be recognised, provision for subjective interpersonal comparisons of utility is necessary for the law of diminishing marginal utility to the incomes to be applied comparatively across different individuals.

While Pigou's motivation for rejecting Pareto's law is evident when his interest in notion of 'disharmony' is recognised, that motivation alone does not explain why much of his attack on that law was mis-specified, not just in terms Pareto's own analysis, but also in terms of his own objectives for criticising Pareto's law. In that regard, (i) intertemporal constancy of $\alpha$ was not a claim that Pareto made; and (ii) discrediting the intertemporal constancy of $\alpha$ does not allow Pigou to illustrate the type of redistribution that he contemplated in Wealth and Welfare as it does not demonstrate the possibility of achieving a welfare gain in the face of a reduction in the national dividend resulting from the introduction of an ex-post nation minimum income to transfer income from the relatively rich to the relatively poor. To achieve that goal he needed to contest the proposition that the logarithmic form of the income distribution curve is accurately represented by a single straight line of slope $\alpha$. Interestingly, Pigou's misreading of Pareto is significant in both the Wealth and Welfare and the Economics of Welfare, although for different reasons in each case.

In Wealth and Welfare, Pigou explicitly accepted the straight line log form of the distribution as accurate for the $19^{\text {th }}$ century cities and countries considered in Pareto's analysis and, when commenting on questions relating to the inequality of income distribution, he did so in terms of the slope of income distribution represented by Pareto's curve.

"it is obvious, however, that a smaller slope of the curve [equation $2 *$ ] means a greater equality of distribution" (Pigou 1912, p.73). 
But Pigou did not appreciate that a reduction in the slope of the income distribution curve will only be associated with a contraction in national income if: (i) the reduction in the slope of the income curve is confined to lower incomes; while (ii) the slope of the curve for higher incomes earners increases. Otherwise, real per capita income would have to increase, as evident from Pareto's discussion of what is referred to as case 2 in this paper. Given his objectives for welfare economics, rather than focusing on the supposed inter-temporal consistency of $\alpha$, to sustain his rejection of Pareto's law, Pigou needed to demonstrate the potential for $\alpha$ to change from a constant value across all income levels, as per equations 1 and 2, to a curve that has at least two distinct values for $\alpha$ that depend on income levels, one slope for people accruing low income and another slope, or other slopes, for people accruing higher incomes. In specific relation to the double log version of the income distribution curve, Pigou needed to demonstrate initially conceptually, then subsequently on an empirical basis - that the single straight line that Pareto had estimated empirically for all income levels can, following the introduction of a new redistribution policy, be modified to form a kinked curve with at least two slopes, as shown in Figures 5 and 6 below.

\section{Figure 5: Log Distribution Curve - 1 kink}

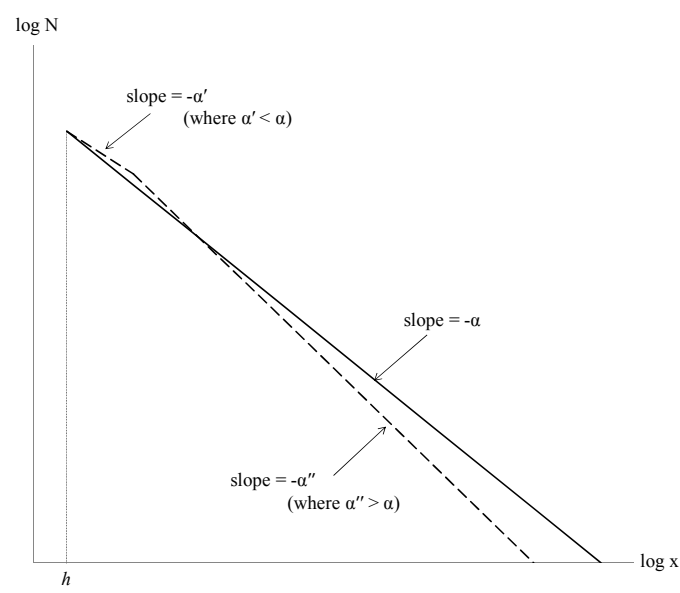

Figure 6: Log Distribution Curve - 2 kinks

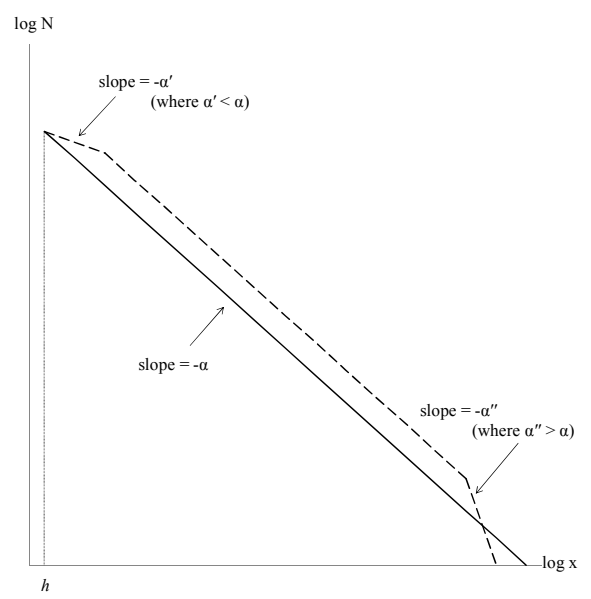

In the Economics of Welfare (1932, p.96), Pigou repeats his misreading of Pareto's measure of inequality. However, he goes part way in the correct direction when 
he notes that Pareto's measure “is very difficult to apply unless we accept Pareto's view that, in any given income distribution, the ratio of his two logarithms is approximately the same for all values of $x$ ". (Pigou 1932, p. 96). But he did not investigate the feasibility or consequences of systematic changes in the slope of the income distribution curve being different for different income levels. ${ }^{12}$ Instead, he said no more on the matter and went on to discuss the conceptual question of whether inequality diminishes with a reduction or increase in $\alpha$, which misses the vital point because the relationship between $\alpha$ and inequality is only considered in the context where $\alpha$ is constant for all values of $x$.

If he had pointed to the possibility of a 'kinked' income distinction curve, especially if he had provided statistical evidence for such a curve in countries that had implemented minimum wage policies, then his rejection of Pareto's law would have been more secure, in the sense that Pareto's analysis of inequality using equation 3 is explicitly predicated on $\alpha$ being the same across low and high incomes, as well as being more consistent with his own objectives for welfare economics, in the sense that two (or more) income specific values for $\alpha$ provide a mechanism for managing 'disharmony' between income equality and efficiency. While his discussion of inheritance, which built upon issues that Pareto had raised in the Manuale, and proportionate changes in forms of income could have been stepping stones from which such issues could be considered, he did not use those discussions to that end.

Even though Pigou's rejection of Pareto's law cannot be sustained in terms of the analytical issues that Pareto raised in support of that law, the rejection itself reveals clear implications for the form of his welfare economics. The 'Pareto welfare criterion', under which a collective welfare improvement is associated with a gain to at least one member of the collective without harming any other member of the collective, is not a necessary criterion for a welfare gain in Pigou's system because he applied a 'subjectively measured' interpersonal compensation criterion to reconcile the efficiency and equality dimensions of welfare economics in the face of 'disharmony'. That is, he makes room

\footnotetext{
${ }^{12}$ In Wealth and Welfare Pigou also qualified his statement that the straight line of equation $2^{*}$ is a reasonable approximation by adding the conditional clause "at least so far as incomes of moderate amount are concerned" (Pigou 1912, p.73). But once again the fundamental problem remains: Pareto's analysis in support of his second theorem cannot be rejected without explicit consideration of the place of all individuals on the income distribution curve, including those who accrue incomes that are above a 'moderate amount'.
} 
for the possibility of subjectively assessed utilitarian benefits from redistribution of income outweighing the welfare loss associated with an 'objective' contraction in economic activity.

This contrasts with the objective 'compensation' principle that Pareto introduced to welfare economics (Pareto 1894 [2008]), under which valuations of individual gain or loss are represented by an objective numeraire good (which amounts to something like an ordinal indicator of each person's individual welfare if one assume that the marginal utility of all economic goods is positive). Pareto's law is potentially consistent with the Pareto welfare criterion, ${ }^{13}$ but Pareto himself did not think of the issue in that way because his curve of income distribution was considered with respect to the dynamic forces of income distribution and not the static analysis (with time considered in a purely 'virtual' sense) that Pareto used to investigate economic welfare issues based on the 'Pareto welfare criterion'. Indeed, he used his notion of the circulation of elites to illustrate the dynamic income gains and losses that individuals face within society:

The outer shape [of the curve of income distribution] varies little; the inner part, on the contrary, is in constant motion: there are individuals who rise to the upper regions, and others who instead fall down. (Pareto 1906 [2006], p. 275)

That is, the dynamic of income distribution reveals gains and losses for individuals even when the collective economic product is increasing in objective terms. However, Pareto's two theorems on the law of income distribution are consistent with his own approach to welfare economics when his objective compensation criterion is introduced in support of the 'Pareto welfare criterion'. Objective compensation, which Pareto first introduces in 'Il Massimo di Utilità dato dalla Libera Concorenza' (Pareto 1894 [2008]), is always possible when a rise in the mean income is associated with a diminution of income inequality, even when the dynamic economic (and political) processes related to both the income level and the distribution of income involve gains for some and losses for others. It is also relevant that in the very same article in which Pareto introduced the objective compensation criterion (Pareto 1894 [2008]), he also discusses the case of efficient redistribution in which there is no contraction in economic activity when the

\footnotetext{
${ }^{13}$ John Chipman (1974) has formally discussed the relationship between Pareto's law and welfare rankings.
} 
minister of production selects coefficients of production that minimise cost and maximise economic output, leaving the minister for justice to determine the fair distribution of income.

Consequently, Pareto's law is: consistent with Pareto's broad conception of welfare economics when the objective compensation criterion is invoked and redistribution is considered without 'destroying wealth'; and inconsistent with the complete system of welfare economics that Pigou was endeavouring to construct.

\section{The Marginal Theory of Distribution and Pigou's Rejection of Pareto's Law}

Pareto's concerns with the marginal productivity theory of distribution were outlined in the Cours and the Manuale, as well as in various articles, and the issue has been systematically reviewed by Henry Schultz (1929). Perhaps the main point that Pareto repeatedly makes is that using the marginal theory of production to derive the coefficient of production assumes that all inputs are variable and independent, but he regarded them as neither necessarily variable, as production involves a combination of fixed and variable factors, nor necessarily independent, because contemporaneous change in the composition of more than one input needs to be considered. ${ }^{14}$ As such, Pareto was of the view that the theory of production should not be predicated on constant returns to scale (Chipman 2002, p4). ${ }^{15}$

\footnotetext{
${ }^{14}$ Pareto's view on this issue proved influential. In his letter of 14 February 1916 to J. B. Clark on the theory of marginal productivity, Philip Wicksteed noted that he had abandoned that theory after reflecting on a comment by Pareto:
}

"I was and am extremely interested in your independent arrival at my old conclusion; and it would be interesting indeed if you were to re-habilitate it after I had abandoned it. But I fear it cannot be done.

What upset me was a remark of Pareto's ... Pareto said that the variables not being independent vitiated the argument. I take that to mean that the factors can never (unless by accident) be combined economically in exactly the same proportions either in two businesses or in the expansion of one. There will always be conditions which affect the relations of the different factors to each other" (Wicksteed, cited in Dorfman 1964, p. 295).

${ }^{15}$ The theory of production that Pareto developed in the Manuale has been criticised by Hans Neisser (1940) for introducing unnecessary complications, but it is relevant that Pareto's mature approach to production is so general in character that it accommodates both marginal and non-marginal equilibria. For 
Having rejected Pareto's law, Pigou immediately raised the possibility of using distribution theory when considering distribution issues. In Wealth and Welfare, the final paragraph of the chapter entitled 'Pareto's law' restates the possibility of 'disharmony', but then diminishes that possibility by shifting his attention back to harmony:

"Although absolute harmony can in no way be demonstrated, good reason can be found for the view that a limited, but, none the less, very important, measure of harmony exists. To display this, it is necessary to undertake some brief discussion of 'the laws of distribution'. The problem of distinguishing the extent to which causes favourable to the one are also favourable to the other calls, therefore, for direct attack. In turning towards it, we find ourselves confronted with the broad problem of distribution" (Pigou 1912, p77).

The next chapter, entitled 'Production and Distribution', considers the 'laws of distribution' in a marginalist manner, with reference to concepts like the 'law of diminishing returns to individual factors of production'.

What then is the significance of Pigou using the last paragraph of his chapter on Pareto's law to introduce the discussion of the marginal theory of distribution that follows in subsequent chapters? While Pigou did not reflect on Pareto's discussion of the marginal theory of distribution, the question that must be asked is whether his rejection of Pareto's law was, from a sociology of scientific knowledge perspective, an attempt to discredit all that Pareto had to say on the issue of distribution, be it empirical or theoretical (including his concerns over the marginal theory of distribution)? The answer appears to be no. Pigou's misreading of Pareto's analysis in defence of his law of distribution suggest that he read Pareto in a non-systematic, even ad hoc, manner and without paying much attention to detail. In light of that, it is likely that his rejection of Pareto's law was solely motivated by a concern with Pareto's second theorem on income distribution. Conversely, it is unlikely that he was motivated by a desire to exclude Pareto's views on the marginal approach to the theory of production and distribution from welfare economics.

example, as Aldo Montesano, Alberto Zanni and Luigino Bruni (2006, pp. 600-602) have already pointed out, the case of production under conditions of decreasing unit costs (implying increasing returns to scale) is not determined by tangency conditions in Pareto's Manuale, rather, it is determined at the 'terminal point' where it is no longer possible to increase profit. 


\section{Conclusion}

Pigou was successful in demonstrating that Pareto's law cannot be sustained if it is justified on the bases of a constant $\alpha$ over time because the statistical evidence does not support the view that $\alpha$ is inter-temporally constant. That finding was, to a considerable extent, sound. The problem for Pigou, however, was that Pareto did not justify the law on the presumption that $\alpha$ was constant over time. He considered that it could be variable, although with only modest change considered.

Like Pareto, Pigou (initially) regarded a diminution of inequality as being associated with a reduction in $\alpha,{ }^{16}$ but, unlike Pareto, he did not appreciate that this necessarily leads to an increase in real per capita income when the Pareto distribution holds and slope $\alpha$ spans all levels of income. If Pigou had followed Pareto's actual deductive analysis and reflected on that analysis in light of his own goals for welfare economics, then Pigou could have criticised the resulting law by noting that equation $2^{*}$ has the potential to 'kink' in response to redistribution policy in a manner that may lead to a contraction in the national dividend. Of course, in the absence of statistics to support such a kink, the proposition would be based on largely speculative analysis, but it would nevertheless have been consistent with the theory that Pigou adopts when discussing transfers and the introduction of a national minimum income. This is not to suggest that Pigou's analysis of Pareto's law should be completely dismissed. For example, his discussion of forces that may lead to weaken the estimate of $\alpha$ by altering the form of the income distribution curve was potentially useful as he developed empirically testable propositions (although he saw the matter in conceptual, rather than empirical, terms and did not test the propositions himself).

But Pigou's rejection of Pareto's law is also important as a specific illustration of Pigou's own approach to welfare economics. It clearly demonstrates the view that the potential for 'disharmony' between redistribution and the level of the national dividend should be treated as a significant (although not dominant) issue in welfare economics. In

\footnotetext{
${ }^{16}$ In Wealth and Welfare Pigou accepted the proposition that a reduction in $\alpha$ leads to a reduction in inequality in the distribution of income; however, in his subsequent The Economics of Welfare, Pigou noted some uncertainty over the relationship between inequality and $\alpha$ (when $\alpha$ is constant over the entire range of income).
} 
that regard, Pigou's theory of welfare economics is designed to contemplate the possibility of a trade-off between wealth, on the one hand, and welfare, on the other. Pareto, however, did not have the same objectives for welfare economics and the consistency between his law of income distribution and the criteria he used for the study of welfare is both clear and significant.

Finally, it is unlikely that Pigou's desire to apply the marginal theory of distribution within his welfare economics was at all related to his rather forceful rejection of Pareto's law of income distribution. There is no evidence in Pigou's writing that he was aware of Pareto's concern with production and distribution theory. When this is considered in conjunction with his misreading of what Pareto actually wrote on the relationship between income inequality and real per capita growth, it may be concluded that Pigou read Pareto in a rather ad hoc manner and with limited care.

\section{References}

Chipman, John S.(1974) 'The Welfare Rankings of Pareto Distributions', Journal of Economic Theory, 9, pp. 275-282

Chipman, John S. (2002) 'Pareto: Manuel of Political Economy", English translation, availabe at http://www.econ.umn.edu/ jchipman/DALLOZ5.pdf, of 'Pareto: Manuel di d'Économie Politique' in Dictionnaire des grandes oeuvres d'économise, X Greffe, j. Lallemant and M De Vroey (eds), Paris: Dalloz, pp. 424433.

Dorfman, Joseph (1964) Wicksteed's Recantation of the Marginal Productivity Theory, Economica, 31(123), pp. 294-295.

Young, Allwyn (1913) 'Wealth and Welfare by A. C. Pigou', Quartely Journal of Economics, 27(4), pp. 672-86.

Maccabelli, Terenzio (2009) 'Measuring Inequality: Pareto's Ambiguos Contribution', History of Political Economy, 41(1), pp. 183-208.

Montesano, Aldo, Alberto Zanni e Luigino Bruni 2006 "Note di Commento" in Pareto, Vilfredo (1906) [2006]. Manuale di Economia Politica. Manuale-Manuel edizione critica a cura di Aldo Montesano, Alberto Zanni e Luigino Bruni, Milan: EGEA Università Bocconi Editore, pp. 577-644..

Neisser, Hans (1940) A Note on Pareto's Theory of Prodcution', Econometrica, 8(3) July, pp. 253-262.

Pareto, Vilfredo (1894) [2008]. 'Il Massimo di Utilità dato dalla Libera Concorenza', Giornale degli Economisti, 4(9): 48-66; English translation 2008, 'The Maximum of Utility given by Free Competition', Giornale degli Economisti e Annali di Economia, Anno 121 67(3): 387-404. 
Pareto, Vilfredo (1896-97) [1971]. Corso di Economia Politica [Cours d'Économie Politique]. Torino: Unione Tipographico-Editrice Torinese.

Pareto, Vilfredo (1906) [2006]. Manuale di Economia Politica. Manuale-Manuel edizione critica a cura di Aldo Montesano, Alberto Zanni e Luigino Bruni, Milan: EGEA - Università Bocconi Editore.

Persky, Joseph (1992) 'Retrospectives: Pareto's Law', Journal of Economic Perspectives, 6(2), pp. 181-192.

Pigou, A. C. (1912). Wealth and Welfare, London: Macmillan.

Pigou, A. C. (1932) [1946]. The Economics of Welfare, Fourth edition. London: Macmillan [earlier editions: 1920 first edition, 1924 second edition and1929 third edition]

Pigou, A. C. (1927). Industrial Fluctuations. London: Macmillan.

Tarascio, V. J. (1973). Pareto's law of income distribution. Social Science Quarterly, vol.54, no.3, pp. 525-533.

Schultz, Henry (1929) 'Marginal Productivity and the General Pricing Process', Journal of political Economy, 37(5), pp. 505-551.

Wood, J. C and Michael McLure (eds) 1999 'Part Eleven: Pareto's Law' in Vilfredo Pareto: Critical Assessments, Volume 4, London: Routledge, pp. 1-299. 
ECONOMICS DISCUSSION PAPERS

2009

\begin{tabular}{|c|c|c|}
\hline $\begin{array}{l}\text { DP } \\
\text { NUMBER }\end{array}$ & AUTHORS & TITLE \\
\hline 09.01 & Le, A.T. & $\begin{array}{l}\text { ENTRY INTO UNIVERSITY: ARE THE CHILDREN OF } \\
\text { IMMIGRANTS DISADVANTAGED? }\end{array}$ \\
\hline 09.02 & $\mathrm{Wu}, \mathrm{Y}$. & CHINA'S CAPITAL STOCK SERIES BY REGION AND SECTOR \\
\hline 09.03 & Chen, M.H. & $\begin{array}{l}\text { UNDERSTANDING WORLD COMMODITY PRICES RETURNS, } \\
\text { VOLATILITY AND DIVERSIFACATION }\end{array}$ \\
\hline 09.04 & Velagic, R. & UWA DISCUSSION PAPERS IN ECONOMICS: THE FIRST 650 \\
\hline 09.05 & McLure, M. & $\begin{array}{l}\text { ROYALTIES FOR REGIONS: ACCOUNTABILITY AND } \\
\text { SUSTAINABILITY }\end{array}$ \\
\hline 09.06 & Chen, A. and Groenewold, N. & $\begin{array}{l}\text { REDUCING REGIONAL DISPARITIES IN CHINA: AN } \\
\text { EVALUATION OF ALTERNATIVE POLICIES }\end{array}$ \\
\hline 09.07 & Groenewold, N. and Hagger, A. & $\begin{array}{l}\text { THE REGIONAL ECONOMIC EFFECTS OF IMMIGRATION: } \\
\text { SIMULATION RESULTS FROM A SMALL CGE MODEL. }\end{array}$ \\
\hline 09.08 & Clements, K. and Chen, D. & AFFLUENCE AND FOOD: SIMPLE WAY TO INFER INCOMES \\
\hline 09.09 & Clements, K. and Maesepp, M. & A SELF-REFLECTIVE INVERSE DEMAND SYSTEM \\
\hline 09.10 & Jones, C. & $\begin{array}{l}\text { MEASURING WESTERN AUSTRALIAN HOUSE PRICES: } \\
\text { METHODS AND IMPLICATIONS }\end{array}$ \\
\hline 09.11 & Siddique, M.A.B. & $\begin{array}{l}\text { WESTERN AUSTRALIA-JAPAN MINING CO-OPERATION: AN } \\
\text { HISTORICAL OVERVIEW }\end{array}$ \\
\hline 09.12 & Weber, E.J. & $\begin{array}{l}\text { PRE-INDUSTRIAL BIMETALLISM: THE INDEX COIN } \\
\text { HYPTHESIS }\end{array}$ \\
\hline 09.13 & McLure, M. & $\begin{array}{l}\text { PARETO AND PIGOU ON OPHELIMITY, UTILITY AND } \\
\text { WELFARE: IMPLICATIONS FOR PUBLIC FINANCE }\end{array}$ \\
\hline 09.14 & Weber, E.J. & $\begin{array}{l}\text { WILFRED EDWARD GRAHAM SALTER: THE MERITS OF A } \\
\text { CLASSICAL ECONOMIC EDUCATION }\end{array}$ \\
\hline 09.15 & Tyers, R. and Huang, L. & $\begin{array}{l}\text { COMBATING CHINA'S EXPORT CONTRACTION: FISCAL } \\
\text { EXPANSION OR ACCELERATED INDUSTRIAL REFORM }\end{array}$ \\
\hline 09.16 & $\begin{array}{l}\text { Zweifel, P., Plaff, D. and } \\
\text { Kühn, J. }\end{array}$ & $\begin{array}{l}\text { IS REGULATING THE SOLVENCY OF BANKS COUNTER- } \\
\text { PRODUCTIVE? }\end{array}$ \\
\hline 09.17 & Clements, $\mathrm{K}$. & THE PHD CONFERENCE REACHES ADULTHOOD \\
\hline 09.18 & McLure, M. & $\begin{array}{l}\text { THIRTY YEARS OF ECONOMICS: UWA AND THE WA } \\
\text { BRANCH OF THE ECONOMIC SOCIETY FROM } 1963 \text { TO } 1992\end{array}$ \\
\hline 09.19 & Harris, R.G. and Robertson, P. & $\begin{array}{l}\text { TRADE, WAGES AND SKILL ACCUMULATION IN THE } \\
\text { EMERGING GIANTS }\end{array}$ \\
\hline 09.20 & $\begin{array}{l}\text { Peng, J., Cui, J., Qin, F. and } \\
\text { Groenewold, N. }\end{array}$ & STOCK PRICES AND THE MACRO ECONOMY IN CHINA \\
\hline 09.21 & Chen, A. and Groenewold, N. & $\begin{array}{l}\text { REGIONAL EQUALITY AND NATIONAL DEVELOPMENT IN } \\
\text { CHINA: IS THERE A TRADE-OFF? }\end{array}$ \\
\hline
\end{tabular}




\begin{tabular}{|c|c|c|}
\hline \multicolumn{3}{|c|}{$\begin{array}{l}\text { ECONOMICS DISCUSSION PAPERS } \\
2010\end{array}$} \\
\hline $\begin{array}{l}\text { DP } \\
\text { NUMBER }\end{array}$ & AUTHORS & TITLE \\
\hline 10.01 & Hendry, D.F. & $\begin{array}{l}\text { RESEARCH AND THE ACADEMIC: A TALE OF } \\
\text { TWO CULTURES }\end{array}$ \\
\hline 10.02 & $\begin{array}{l}\text { McLure, M., Turkington, D. and Weber, } \\
\text { E.J. }\end{array}$ & A CONVERSATION WITH ARNOLD ZELLNER \\
\hline 10.03 & $\begin{array}{l}\text { Butler, D.J., Burbank, V.K. and } \\
\text { Chisholm, J.S. }\end{array}$ & $\begin{array}{l}\text { THE FRAMES BEHIND THE GAMES: PLAYER'S } \\
\text { PERCEPTIONS OF PRISONER'S DILEMMA, } \\
\text { CHICKEN, DICTATOR, AND ULTIMATUM } \\
\text { GAMES }\end{array}$ \\
\hline 10.04 & Harris, R.G., Robertson, P.E. and Xu, J.Y. & $\begin{array}{l}\text { THE INTERNATIONAL EFFECTS OF CHINA'S } \\
\text { GROWTH, TRADE AND EDUCATION BOOMS }\end{array}$ \\
\hline 10.05 & Clements, K.W., Mongey, S. and Si, J. & $\begin{array}{l}\text { THE DYNAMICS OF NEW RESOURCE } \\
\text { PROJECTS A PROGRESS REPORT }\end{array}$ \\
\hline 10.06 & Costello, G., Fraser, P. and Groenewold, N. & $\begin{array}{l}\text { HOUSE PRICES, NON-FUNDAMENTAL } \\
\text { COMPONENTS AND INTERSTATE SPILLOVERS: } \\
\text { THE AUSTRALIAN EXPERIENCE }\end{array}$ \\
\hline 10.07 & Clements, $\mathrm{K}$. & $\begin{array}{l}\text { REPORT OF THE } 2009 \text { PHD CONFERENCE IN } \\
\text { ECONOMICS AND BUSINESS }\end{array}$ \\
\hline 10.08 & Robertson, P.E. & $\begin{array}{l}\text { INVESTMENT LED GROWTH IN INDIA: HINDU } \\
\text { FACT OR MYTHOLOGY? }\end{array}$ \\
\hline 10.09 & Fu, D., Wu, Y. and Tang, Y. & $\begin{array}{l}\text { THE EFFECTS OF OWNERSHIP STRUCTURE } \\
\text { AND INDUSTRY CHARACTERISTICS ON } \\
\text { EXPORT PERFORMANCE }\end{array}$ \\
\hline 10.10 & $\mathrm{Wu}, \mathrm{Y}$. & $\begin{array}{l}\text { INNOVATION AND ECONOMIC GROWTH IN } \\
\text { CHINA }\end{array}$ \\
\hline 10.11 & Stephens, B.J. & $\begin{array}{l}\text { THE DETERMINANTS OF LABOUR FORCE } \\
\text { STATUS AMONG INDIGENOUS AUSTRALIANS }\end{array}$ \\
\hline 10.12 & Davies, $\mathrm{M}$. & $\begin{array}{l}\text { FINANCING THE BURRA BURRA MINES, } \\
\text { SOUTH AUSTRALIA: LIQUIDITY PROBLEMS } \\
\text { AND RESOLUTIONS }\end{array}$ \\
\hline 10.13 & Tyers, R. and Zhang, Y. & APPRECIATING THE RENMINBI \\
\hline 10.14 & Clements, K.W., Lan, Y. and Seah, S.P. & $\begin{array}{l}\text { THE BIG MAC INDEX TWO DECADES ON } \\
\text { AN EVALUATION OF BURGERNOMICS }\end{array}$ \\
\hline 10.15 & Robertson, P.E. and Xu, J.Y. & $\begin{array}{l}\text { IN CHINA'S WAKE: } \\
\text { HAS ASIA GAINED FROM CHINA'S GROWTH? }\end{array}$ \\
\hline 10.16 & Clements, K.W. and Izan, H.Y. & $\begin{array}{l}\text { THE PAY PARITY MATRIX: A TOOL FOR } \\
\text { ANALYSING THE STRUCTURE OF PAY }\end{array}$ \\
\hline 10.17 & Gao, G. & WORLD FOOD DEMAND \\
\hline 10.18 & $\mathrm{Wu}, \mathrm{Y}$ & $\begin{array}{l}\text { INDIGENOUS INNOVATION IN CHINA: } \\
\text { IMPLICATIONS FOR SUSTAINABLE GROWTH }\end{array}$ \\
\hline 10.19 & Robertson, P.E. & DECIPHERING THE HINDU GROWTH EPIC \\
\hline
\end{tabular}




\begin{tabular}{|l|l|l|}
\hline 10.20 & Stevens, G. & $\begin{array}{l}\text { RESERVE BANK OF AUSTRALIA-THE ROLE OF } \\
\text { FINANCE }\end{array}$ \\
\hline 10.21 & Widmer, P.K., Zweifel, P. and Farsi, M. & $\begin{array}{l}\text { ACCOUNTING FOR HETEROGENEITY IN THE } \\
\text { MEASUREMENT OF HOSPITAL PERFORMANCE }\end{array}$ \\
\hline 10.22 & McLure, M. & $\begin{array}{l}\text { ASSESSMENTS OF A. C. PIGOU'S FELLOWSHIP } \\
\text { THESES }\end{array}$ \\
\hline 10.23 & Poon, A.R. & $\begin{array}{l}\text { THE ECONOMICS OF NONLINEAR PRICING: } \\
\text { EVIDENCE FROM AIRFARES AND GROCERY } \\
\text { PRICES }\end{array}$ \\
\hline 10.24 & Halperin, D. & $\begin{array}{l}\text { FORECASTING METALS RETURNS: A } \\
\text { BAYESIAN DECISION THEORETIC APPROACH }\end{array}$ \\
\hline 10.25 & Clements, K.W. and Si. J. & $\begin{array}{l}\text { THE INVESTMENT PROJECT PIPELINE: COST } \\
\text { ESCALATION, LEAD-TIME, SUCCESS, FAILURE } \\
\text { AND SPEED }\end{array}$ \\
\hline 10.26 & Chen, A., Groenewold, N. and Hagger, A.J. & $\begin{array}{l}\text { THE REGIONAL ECONOMIC EFFECTS OF A } \\
\text { REDUCTION IN CARBON EMISSIONS }\end{array}$ \\
\hline 10.27 & $\begin{array}{l}\text { Siddique, A., Selvanathan, E.A. and } \\
\text { Selvanathan, S. }\end{array}$ & $\begin{array}{l}\text { REMITTANCES AND ECONOMIC GROWTH: } \\
\text { EMPIRICAL EVIDENCE FROM BANGLADESH, } \\
\text { INDIA AND SRI LANKA }\end{array}$ \\
\hline
\end{tabular}




\begin{tabular}{|c|c|c|}
\hline \multicolumn{3}{|c|}{$\begin{array}{l}\text { ECONOMICS DISCUSSION PAPERS } \\
2011\end{array}$} \\
\hline $\begin{array}{l}\text { DP } \\
\text { NUMBER }\end{array}$ & AUTHORS & TITLE \\
\hline 11.01 & Robertson, P.E. & $\begin{array}{l}\text { DEEP IMPACT: CHINA AND THE WORLD } \\
\text { ECONOMY }\end{array}$ \\
\hline 11.02 & Kang, C. and Lee, S.H. & $\begin{array}{l}\text { BEING KNOWLEDGEABLE OR SOCIABLE? } \\
\text { DIFFERENCES IN RELATIVE IMPORTANCE OF } \\
\text { COGNITIVE AND NON-COGNITIVE SKILLS }\end{array}$ \\
\hline 11.03 & Turkington, D. & DIFFERENT CONCEPTS OF MATRIX CALCULUS \\
\hline 11.04 & Golley, J. and Tyers, R. & $\begin{array}{l}\text { CONTRASTING GIANTS: DEMOGRAPHIC CHANGE } \\
\text { AND ECONOMIC PERFORMANCE IN CHINA AND } \\
\text { INDIA }\end{array}$ \\
\hline 11.05 & Collins, J., Baer, B. and Weber, E.J. & $\begin{array}{l}\text { ECONOMIC GROWTH AND EVOLUTION: } \\
\text { PARENTAL PREFERENCE FOR QUALITY AND } \\
\text { QUANTITY OF OFFSPRING }\end{array}$ \\
\hline 11.06 & Turkington, D. & $\begin{array}{l}\text { ON THE DIFFERENTIATION OF THE LOG } \\
\text { LIKELIHOOD FUNCTION USING MATRIX } \\
\text { CALCULUS }\end{array}$ \\
\hline 11.07 & Groenewold, N. and Paterson, J.E.H. & $\begin{array}{l}\text { STOCK PRICES AND EXCHANGE RATES IN } \\
\text { AUSTRALIA: ARE COMMODITY PRICES THE } \\
\text { MISSING LINK? }\end{array}$ \\
\hline 11.08 & Chen, A. and Groenewold, N. & $\begin{array}{l}\text { REDUCING REGIONAL DISPARITIES IN CHINA: IS } \\
\text { INVESTMENT ALLOCATION POLICY EFFECTIVE? }\end{array}$ \\
\hline 11.09 & Williams, A., Birch, E. and Hancock, P. & $\begin{array}{l}\text { THE IMPACT OF ON-LINE LECTURE RECORDINGS } \\
\text { ON STUDENT PERFORMANCE }\end{array}$ \\
\hline 11.10 & Pawley, J. and Weber, E.J. & $\begin{array}{l}\text { INVESTMENT AND TECHNICAL PROGRESS IN THE } \\
\text { G7 COUNTRIES AND AUSTRALIA }\end{array}$ \\
\hline 11.11 & Tyers, R. & $\begin{array}{l}\text { AN ELEMENTAL MACROECONOMIC MODEL FOR } \\
\text { APPLIED ANALYSIS AT UNDERGRADUATE LEVEL }\end{array}$ \\
\hline 11.12 & Clements, K.W. and Gao, G. & QUALITY, QUANTITY, SPENDING AND PRICES \\
\hline 11.13 & Tyers, R. and Zhang, Y. & $\begin{array}{l}\text { JAPAN'S ECONOMIC RECOVERY: INSIGHTS FROM } \\
\text { MULTI-REGION DYNAMICS }\end{array}$ \\
\hline 11.14 & McLure, M. & A. C. PIGOU’S REJECTION OF PARETO’S LAW \\
\hline 11.15 & Kristoffersen, I. & $\begin{array}{l}\text { THE SUBJECTIVE WELLBEING SCALE: HOW } \\
\text { REASONABLE IS THE CARDINALITY } \\
\text { ASSUMPTION? }\end{array}$ \\
\hline 11.16 & Clements, K.W., Izan, H.Y. and Lan, Y. & VOLATILITY AND STOCK PRICE INDEXES \\
\hline 11.17 & Parkinson, M. & $\begin{array}{l}\text { SHANN MEMORIAL LECTURE 2011: SUSTAINABLE } \\
\text { WELLBEING - AN ECONOMIC FUTURE FOR } \\
\text { AUSTRALIA }\end{array}$ \\
\hline
\end{tabular}

